cultural and historical studies. On the second expedition, Mr. L. P. Kirwan, a well-known archæologist, will visit the Aden Protectorate for the purpose of inspecting and examining a number of archæological sites between Aden and Lahej. He will visit Amadiya on the Audhali Plateau, which will be surveyed, and the ruins of Qohlan in Wadi Beihan. Mr. Kirwan will also examine and report on the archæological material in the Aden Museum, which is now in process of being reorganized.

\section{Exhibition of Chinese Art}

AN exhibition has been arranged in the North Court of the Victoria and Albert Museum, South Kensington, which illustrates comprehensively the whole range of Chinese art from the prehistoric period at about 3000 B.c. down to modern times. With the exception of a small series to be seen in the Department of Ceramics, this exhibition includes all the objects of Chinese art of all kinds now in the possession of the Museum. It includes the Museum's share of the Eumorfopoulos collection, which provides some of the most striking and widely known exhibits. The arrangement of the exhibition is chronological and cultural. Each exhibit is grouped with others, whatever their character or material, whether of jade, textile, painting or pottery, provided they belong to the same period and are of the same cultural origin. The first and earliest exhibit is a neolithic pot of about 3000 B.C. A special feature of the exhibition is the important collection of ritual bronzes, which has been provided with special caselabels incorporating small photographs, illustrating the main features of style. A collection of Buddhist sculpture of the fifth and sixth century A.D. is on loan from Baron von der Heydt. Especially noteworthy are two wooden sculptures, one a figure of Kuan Yin, Goddess of Mercy, dating from the twelfth century, and a statue of a seated man, belonging to the fifteenth century. The exhibition is to be permanently on view.

\section{British Museum (Bloomsbury) : Recent Acquisitions}

Accessions to the collections of antiquities and ethnographical objects in the British Museum (Bloomsbury) of exceptional interest were reported at the meeting of the Trustees on March 11. Of these one is a remarkably fine example of the Irish twisted gold torque, which has been accepted on loan for temporary exhibition from the Duke of Westminster. It is made from a single bar of gold, 50 inches long and weighing $26 \mathrm{oz}$. It has been chiselled and beaten into four flanges and then twisted and bent into a circle. The ends are recurved to fit into one another to form a fastening. It is of a type characteristic of the Middle Bronze Age and dates from about 1200 B.c. It was found in 1816 at Bryn Sion Farm, Flintshire. Another accession to the Department of British Antiquities is a collection of fragments of pots of dark earthenware, freely ornamented towards the top with hatchings, pitting, and finger-nail marks, presented by Mr. J. P. T.
Burchell. They were excavated by him in the Ebbs. fleet Valley, Kent, at a depth of $10 \mathrm{ft}$. in stratigraphical conditions, which make it certain that this pottery is older than the neolithic period as at present understood. It is possible that this may prove to be the oldest pottery as yet found in Britain. It would seem to be connected with mesolithic types found on the Continent, such as those from the Danish kitchenmiddens. It differs from British 'Neolithic A', and may indeed prove to be a predecessor of 'Peterborough' ware. Another accession of considerable archæological interest is a human face, almost circular in outline, carved on a piece of Bath stone found near Charterhouse-on-Mendip. It has almondshaped eyes and a small round hole for a mouth. It dates from the period of Roman occupation; but is thought to represent a native barbaric tradition. Of the ethnographical accessions the most striking is a wooden totenic figure of an eagle made by the Siwash Indians of Vancouver Island. It stands about four feet high, with wings half-spread, and is painted in gaudy colours, and has a fierce human face painted on the breast.

\section{British Museum (Natural History): Recent Acquisitions}

The Mineral Department of the British Museum (Natural History) has acquired through Mr. Arthur Russell a small collection of foreign minerals from the collection of Philip Rashleigh, F.R.S., of Menabilly, near Fowey, Cornwall (1729-1811). The main part of the Rashleigh Collection is in the Truro Museum. Mr. Arthur Champion has collected rocks from various localities on a remarkable motor journey he made in 1937 from Dakar to Nairobi. The collection includes specimens from French West Africa and the Belgian Congo as well as from Senegal, Gold Coast and Nigeria. A fine specimen of the mineral thortveitite has been received from Prof. T. Vogt of Trondhjem, Norway, and suitable specimens have been sent him in exchange.

\section{Broadcasting in 1938}

THE report of the Governors of the British Broadcasting Corporation for the year ended December 31, 1938, as presented to His Majesty's PostmasterGeneral, has recently been published as a white paper (Cmd. 5951. London: H.M. Stationery Office. $6 d$. net). The scope of the report is indicated by the headings of the main sections into which it is divided, namely, programmes, public relations, engineering and administration. During the year under review, the Corporation suffered a loss by the resignations of its first director-general, Sir John Reith, and of the deputy director-general, Vice-Admiral Sir Charles Carpendale. Mr. F. W. Ogilvie was appointed to the first position, while Mr. C. G. Graves became the new deputy director-general. The staff of the B.B.C. is now more than four thousand, and these have provided to nearly nine million licensed listeners a home broadcasting service of some 79,500 hours in 1938, with the remarkably small breakdown time of 0.023 per cent. In addition, nearly 33,000 hours 
of Empire programmes were provided, while the aggregate time of operation for the television sound and vision transmitters has increased from 1,619 hours in 1937 to 2,679 hours in 1938. Among the increased programme facilities provided during the past year were daily news services in Arabic for listeners in the Near and Middle East, and in Spanish and Portuguese for listeners in Latin-American countries. Towards the end of the year, also, daily news services, intended primarily for European reception, were broadcast in French, German and Italian.

ON the engineering side, a new medium wave transmitting station was opened at Aberdeen in September ; and the construction of a new high-power transmitting station at Start Point in South Devon, and of a medium-power station at Clevedon, Somerset, is proceeding satisfactorily. The number of transmitters normally in use at the Daventry short-wave station has been increased from four to six, so that larger areas may be covered for longer periods. Further expansion is in hand at this station, including the provision of new transmitters and aerial systems. The scope of the television programmes has been considerably extended during 1938 by the provision of increased studio facilities at Alexandra Palace, by the purchase of a second mobile television unit for outside broadcasts, and by the establishment of improved relay link arrangements for such broadcasts. The report concludes with a statement of the financial position as at December 31, 1938.

\section{Antarctic Whaling}

ThE Polar Record for January, a journal which has now widened its scope to include various articles in addition to news of polar expeditions, contains some details of the International Whaling Agreement of 1938. The measures agreed on in 1937 included a minimum size limit for various species, the restriction of the Antarctic whaling season from December 8 to March 7 and the prohibition of pelagic whaling in temperate and tropical waters. Last year the conference went further, though it was decided that restrictions on the numbers of whale catchers were impracticable at present. It was, however, agreed to prohibit the killing of humpback whales in waters south of lat. $40^{\circ} \mathrm{S}$. for one year. This species is more vulnerable than blue and fin whales, and it is hoped thus to save the stock from exhaustion. It was also decided to prohibit all pelagic whaling for at least two years in the Pacific waters south of lat. $40^{\circ} \mathrm{S}$. between long. $70^{\circ} \mathrm{W}$. and $100^{\circ} \mathrm{W}$. These waters so far have no pelagic or other whalers and so may well serve as a sanctuary for hunted species. In spite of these restrictions, it is admitted that the industry as a whole is probably taking an unduly large number of whales.

\section{Australian Cancer Research}

THE present position of organizations combating cancer in the Antipodes can be seen from the report of the ninth Australian Cancer Conference held in Sydney during April 5-8, 1938 (Canberra : Govern- ment Printer, 1938). In many centres of the Commonwealth, new radiological plant has been installed and old apparatus improved, and attempts are being made to improve facilities for diagnosis in country districts. In an address given on the occasion of the Conference, Prof. E. C. Dodds pleaded for development of general research in basic sciences as being probably the best way of helping existing lines of cancer research. Dr. Robert Fowler discussed the research value of clinical records with particular reference to the 'follow-up' of cancer patients, and considered in some detail the indexing of cases. In a population of six and a half millions in Australia there were more than 7,500 deaths from cancer during 1936. A statistical examination of this cancer mortality was made by Dr. M. T. Holmes, who also summarized the results of treatment with radium at Australian centres over a nine-year period. Of 35,000 cases treated with radium, less than 10 per cent showed no improvement. Examination of data along similar lines should indicate how methods of treatment develop and how they compare with those of other countries.

\section{The Dutch Physical and Medical Congress}

THe twenty-seventh Dutch Physical and Medical Congress will be held at Nijmegen during April 1113, 1939, under the presidency of Dr. G. Holst. General lectures will be given by Dr. G. Holst on "The Properties of Magnetic Materials" and by Prof. B. Brouwer on "The Significance of the Hydrodynamic Relations within the Skull Cavity and the Semicircular Canal for Neural Surgery" on April 11, and by Prof. L. S. Ornstein on "Physics and Biology" and by Prof. E. Gorter on "Very Thin Films" on April 12. The scientific work of the meeting will be dealt with in the four sections: Mathematical and Physical Sciences, Biological Sciences, Medical Sciences, Geological-Geographical Sciences, some seventy papers having been promised. A full pro. gramme of social functions, visits to factories, laboratories, hospitals and other places of interest has been arranged. Information can be obtained from the "Natuuren Geneeskundig Congresbureau", Bureau Vreemdelingenverkeer, Keizer Karelplein 9, Nijmegen, Holland.

\section{Kathleen Schlesinger Research Fellowship}

ThE Medical Research Council invite applications for the Kathleen Schlesinger research fellowship which has been provided from a fund established by the late Mr. Eugen M. Schlesinger and Mrs. Schlesinger in memory of their daughter. It will be awarded to a suitably qualified person who will devote his or her whole time to "investigating the origin and nature of cysts of the brain whether arising from tumours or not or to such studies of other conditions of the central nervous system as the Council may from time to time permit". It will ordinarily be tenable at the National Hospital for Diseases of the Nervous System, Queen Square, London, and for a period of one year in the first instance. The stipend will be at the rate of $£ 300$ per 